\title{
EVALUASI KINERJA STRUKTUR GEDUNG DUAL SYSTEM BERBASIS KINERJA
}

\author{
Dave Fernando Indotjoa ${ }^{1}$, Daniel Christianto ${ }^{2}$ dan Hadi Pranata ${ }^{3}$ \\ ${ }^{1}$ Program Studi Sarjana Teknik Sipil, Universitas Tarumanagara, Jl. Letjen S. Parman No.1 Jakarta \\ Email: devfernand27@gmail.com \\ ${ }^{2}$ Program Studi Sarjana Teknik Sipil, Universitas Tarumanagara, Jl. Letjen S. Parman No.1 Jakarta \\ Email: daniel@untar.ac.id \\ ${ }^{3}$ Program Studi Sarjana Teknik Sipil, Universitas Tarumanagara, Jl. Letjen S. Parman No.1 Jakarta \\ Email: hp.rematha@gmail.com
}

\begin{abstract}
ABSTRAK
Struktur penahan gaya gempa secara umum memakai konsep Force Based Design. Konsep dari Force Based Design hanya berdasarkan kondisi elastis struktur dan tidak sesuai dengan kondisi sebenarnya dimana struktur gedung mengalami kondisi inelastis ketika mengalami peristiwa gempa. Sehingga perlu dilakukan analisis evaluasi kinerja struktur untuk mengetahui kinerja gedung ketika mencapai kondisi inelastis yang merupakan konsep Performance Based Design. Dalam penilitian ini terdapat dua metode yang dipakai untuk analisis gedung ketika mengalami kondisi inelastis, yaitu metode Direct Displacement Based Design dan metode analisis Pushover. Tujuan dalam penelitian ini untuk mengidentifikasi dan membandingkan kinerja struktur bangunan antara metode-metode tersebut. Penelitian digunakan program ETABS untuk mengetahui berapa besar gaya dan perpindahan yang dapat ditahan oleh struktur. Melalui program ETABS dapat diketahui pula level kinerja struktur bangunan tersebut. Tipe struktur bangunan yang dimodelkan berupa bangunan dengan sistem ganda. Bangunan terbuat dari beton bertulang, jarak bentang arah memanjang $53.7 \mathrm{~m}$, jarak bentang arah memendek $36.2 \mathrm{~m}$, dengan ketinggian $64.5 \mathrm{~m}$, tinggi tiap lantai $4.3 \mathrm{~m}$. Penelitian mengacu pada SNI 1726:2012, ATC-40, FEMA 356, dan FEMA 440.
\end{abstract}

Kata kunci: kinerja gedung, inelastis, pushover, sistem ganda, direct displacement based design.

\section{PENDAHULUAN}

\section{Latar Belakang}

Peristiwa gempa merupakan bencana alam yang sangat berpengaruh terhadap bangunan, terutama pada bangunan tinggi. Perencanaan struktur bangunan gedung tahan gempa sangat penting di Indonesia, mengingat wilayahnya yang berada di jalur gempa Pasifik (Circum Pasific Earthquake Belt) dan jalur gempa Asia (Trans Asiatic Earthquake Belt) sehingga tingkat risiko terjadinya gempa bumi sangatlah tinggi. Dengan risiko terjadinya gempa yang sangatlah tinggi, maka sangat tinggi pula risiko kerusakan bangunan yang akan terjadi.

Konsep terbaru dalam perencanaan gempa saat ini adalah perencanaan berbasis kinerja yang dikenal dengan Performance Based Design. Konsep perencanaan berbasis kinerja merupakan kombinasi dari aspek tahanan dan aspek layan. Dalam perencanaan ini, kinerja struktur dual system terhadap gempa ketika kondisi inelastis dianalisis dengan metode Direct Displacement Based Design dimana dalam mendesain kekuatan yang diperlukan struktur bertujuan untuk mencapai target perpindahan serta kinerja batas yang telah direncanakan, dan pola keruntuhan dalam perencanaan ini dapat dinyatakan secara jelas dalam bentuk kurva. Untuk mengetahui perilaku keruntuhan pada bangunan maka digunakan analisis statik nonlinier atau analisis Pushover.

Prosedur analisis Pushover sesuai konsep Performance Based Earthquake Engineering yaitu Capacity Spectrum Method (CMS) berdasarkan peraturan ATC-40 dan Displacement Coefficient Method (DCM) berdasarkan peraturan FEMA 356 dan FEMA 440. Dari hasil analisis, dapat digambarkan hubungan antara base shear dan roof displacement, hubungan tersebut kemudian dipetakan sebagai kurva kapasitas struktur. Selain itu, analisis Pushover juga dapat memperlihatkan secara visual perilaku struktur gedung saat kondisi elastis, plastis dan sampai terjadi keruntuhan pada elemen strukturnya.

\section{Identifikasi Permasalahan}

Permasalahan yang akan dibahas adalah mengevaluasi gedung dengan sistem penahan gaya gempa untuk dual system dengan perencanaan berbasis kinerja. 


\section{Batasan Masalah}

Dalam penilitian ini, batasan masalahnya adalah sebagai berikut:

1. Sistem penahan gaya gempa pada struktur dengan dual system dengan rangka pemikul momen khusus.

2. Beban gempa rencana yang digunakan sebagai basic design adalah beban gempa dengan menurut SNI 1726:2012.

3. Model struktur yang digunakan di ambil sampel struktur gedung 16 lantai.

4. Pemodelan dinding geser untuk analisis statik pushover sebagai model mid-pier frame.

5. Diafragma pelat dianggap rigid.

6. Model struktur gedung dianggap beraturan.

7. Penulangan balok, kolom, dan dinding geser dengan dimensi yang sama dirancang memiliki tulangan yang sama.

8. Pondasi dianggap jepit sempurna.

9. Analisis untuk perencanaan gedung berbasis kinerja menggunakan direct diplacement based design dan analisis pushover menurut peraturan ATC-40, FEMA 356, dan FEMA 440.

\section{Rumusan Masalah}

Adapun beberapa masalah yang akan di singkap pada penelitian ini adalah:

1. Bagaimana pemodelan dinding geser bersayap $\mathrm{C}$ pada gedung dengan menggunakan mid-pier frame.

2. Bagaimana kurva kapasitas dan pola keruntuhan yang terjadi pada gedung dengan analisis pushover.

3. Bagaimana perencanaan gempa dengan SNI 1726:2012 yang dievaluasi dengan analisis pushover dan metode direct displacement based design.

4. Bagaimana level kinerja struktur pada gedung yang direncanakan dengan peraturan SNI 1726:2012 melalui analisis pushover menurut peraturan ATC-40, FEMA 356, dan FEMA 440.

\section{Tujuan Penilitian}

Tujuan dari penilitian ini :

1. Untuk mengetahui bagaimana pemodelan dinding geser bersayap C pada gedung dengan menggunakan mid-pier frame.

2. Untuk memperlihatkan kurva kapasitas dan pola keruntuhan yang terjadi pada gedung dengan analisis pushover.

3. Untuk mengetahui bagaimana perencanaan gempa dengan SNI 1726:2012 yang dievaluasi dengan analisis pushover dan metode direct displacement based design.

4. Untuk mengetahui bagaimana level kinerja struktur pada gedung yang direncanakan dengan peraturan SNI 1726:2012 melalui analisis pushover menurut peraturan ATC-40, FEMA 356, dan FEMA 440.

\section{KAJIAN PUSTAKA}

\section{Prosedur DDBD untuk Sistem Ganda}

Step by step untuk menentukan nilai gaya geser dasar desain untuk struktur dengan sistem ganda adalah sebagai berikut:

\section{Desain Proporsi Gaya Geser pada Rangka dan Dinding Geser}

Langkah pertama dalam desain menggunakan metode Direct Displacement Based Design untuk struktur dengan sistem ganda (dual system) adalah menentukan proporsi gaya geser yang akan diterima oleh sistem rangka dan dinding geser. Dimana proporsi gaya geser pada frame ditentukan dengan Persamaan 1a dan 1b.

$$
\begin{aligned}
& V_{F}=\beta_{F} V_{\text {Base }} \\
& V_{W}=\left(1-\beta_{F}\right) V_{\text {Base }}
\end{aligned}
$$

Dengan $V_{F}=$ gaya geser dasar pada rangka,$V_{W}=$ gaya geser dasar pada dinding geser, $V_{B a s e}=$ gaya geser dasar total, dan $\beta_{F}=$ Rasio gaya geser dasar pada rangka. 


\section{Menentukan Tinggi Wall Contraflexture $\left(\boldsymbol{H}_{C F}\right)$}

Tinggi dinding pada kondisi contraflexture/inflection diilustrasikan seperti pada Gambar 1. Nilai $H_{C F}$ akan bervariasi sesuai dengan besar gaya geser dasar yang mampu ditahan oleh rangka $\left(V_{F}\right)$ terhadap gaya geser total $\left(V_{\text {Bass }}\right)$.

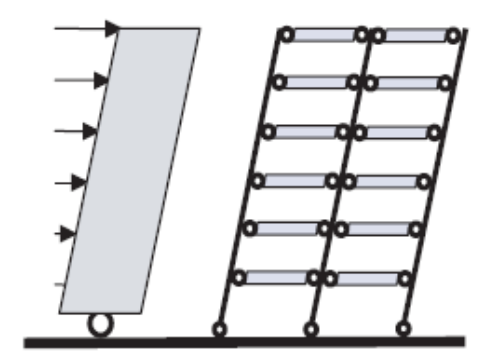

BEAM-SWAY MECHANISM

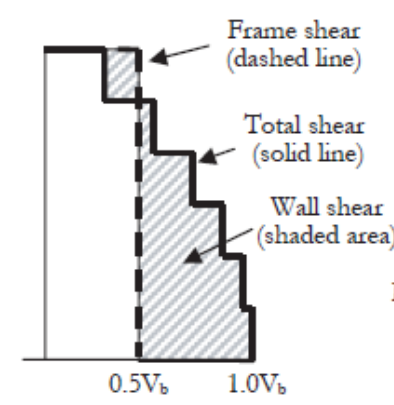

SHEARS

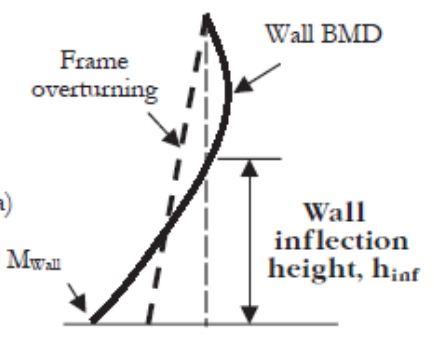

MOMENTS

Gambar 1. Tinggi dinding contraflexure berdasarkan proporsi gaya geser

Nilai overturning moment relatif dapat dihitung dengan Persamaan 3 setelah nilai-nilai gaya geser dasar relatif, $V$ dihitung.

$$
\begin{aligned}
& F_{i}=\frac{M_{i} H_{i}}{\sum M_{i} H_{i}} \\
& M \text { oTM } \cdot i=V_{i} \times H_{n}
\end{aligned}
$$

Dengan $F_{i}=$ rasio gaya relatif lantai ke-i, $m_{i}=$ massa pada lantai ke-i, $H_{i}=$ total tinggi struktur lantai ke-i, $M_{\text {oTM.i }}=$ total momen overturning lantai ke-i, $V_{i}=$ total gaya geser lantai ke-i, dan $H_{n}=$ tinggi struktur pada lantai ke-i.

\section{Desain Profil Perpindahan Rencana}

Sehingga nilai profil perpindahan rencana dapat dihitung menggunakan Persamaan 4.

$$
\Delta_{D i}=\Delta_{y i}+\Delta_{p i}
$$

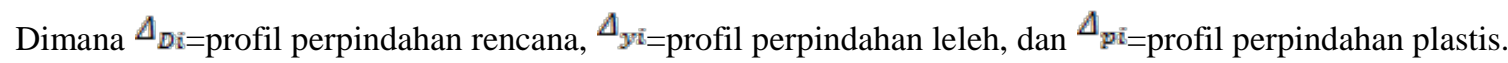

\section{Desain Perpindahan SDOF}

Desain perpindahan tingkat $M D O F$ harus dikonversi ke sistem SDOF dimana perpindahan maksimum merupakan ekuivalen dari desain perpindahan tingkat MDOF dengan Persamaan 5.

$$
\Delta_{d}=\frac{\sum_{i=1}^{n}\left(m_{i} \Delta_{i}^{2}\right)}{\sum_{i=1}^{n}\left(m_{i} \Delta_{i}\right)}
$$

Dimana $\Delta_{d}=$ perpindahan maksimum rencana $S D O F, m_{i}=$ massa pada tingkat ke-i, dan $\Delta_{i}=$ perpindahan pada lantai ke-i.

\section{Tinggi Efektif}

Tinggi efektif struktur yang setara dengan sistem SDOF, dapat dihitung dengan Persamaan 6.

$$
H_{e}=\frac{\sum_{i=1}^{n}\left(m_{i} \Delta_{i} h_{i}\right)}{\sum_{i=1}^{n}\left(m_{i} \Delta_{i}\right)}
$$

Dimana $H_{c}=$ tinggi efektif struktur. 


\section{Massa Efektif}

Massa efektif untuk sistem SDOF untuk sistem rangka dihitung dengan Persamaan 7.

$$
m_{e}=\frac{\sum_{i=1}^{n}\left(m_{i} \Delta_{i}\right)}{\Delta_{d}}
$$

Dimana $m_{c}=$ massa efektif.

\section{Redaman Viscous Ekuivalen (Equivalent Viscous Damping)}

Perhitungan untuk daktilitas perpindahan pada dinding geser dihitung dengan Persamaan 8, dan untuk redaman viscous ekuivalen pada dinding geser beton bertulang dihitung dengan Persamaan 9.

$$
\begin{gathered}
\mu_{W}=\Delta_{d} / \Delta_{y W} \\
\xi_{w}=0.05+0.444\left(\frac{\mu_{W}-1}{\mu_{W} \pi}\right)
\end{gathered}
$$

Dimana $\mu_{W}=$ daktilitas perpindahan dinding geser, $\Delta_{y w}=$ perpindahan leleh pada dinding geser saat mencapai tinggi efektif, dan $\xi_{W}=$ Redaman efektif $R C$-Wall terhadap arah yang ditinjau.

Untuk sehingga nilai redaman ekuivalen untuk sistem SDOF pada sistem ganda dapat dihitung dengan Persamaan 10.

$$
\xi_{e q}=\frac{M_{O T M, W} \xi_{\text {EW }}+M_{O T M . F} \xi_{F}}{M_{O T M}}
$$

Dimana $\xi_{\Theta q}=$ Redaman efektif ekuivalen (equivalent viscous damping), $\xi_{W}=$ Redaman efektif $R C$-Wall terhadap arah yang ditinjau, dan $\xi_{F}=$ Redaman efektif frame beton bertulang efektif terhadap arah yang ditinjau.

\section{Distribusi Gaya Geser Dasar DDBD}

Nilai gaya geser dasar ini akan didistribusikan pada tiap-tiap lantai $\left(F_{i}\right)$ dengan Persamaan 11 pada pusat massa bangunan.

$$
F_{i}=F_{t}+0.9 V_{\text {base }}\left(m_{i} \Delta_{i}\right) / \sum_{i=1}^{n}\left(m_{i} \Delta_{i}\right)
$$

Dimana $V_{\text {base }}=$ gaya geser desain, $\Delta_{i=}$ perpindahan yang terjadi pada lantai ke-i, dan $F_{t}=0,1 \times V_{b a s e}$, untuk lantai atap.

\section{Kinerja Struktur Metode ATC-40}

Dalam metode ATC-40, metode yang digunakan untuk menentukan tingkat kinerja dari struktur adalah dengan metode spektrum kapasitas atau Capacity Spectrum Method (CSM). Metode spektrum kapasitas adalah dengan memplotkan demand respon spektrum dan kurva kapasitas dalam satu format antara spektral percepatan vs spektral perpindahan atau disebut sebagai format Acceleration-Displacement Response Spectra (ADRS).

Untuk merubah kurva kapasitas kedalam format ADRS maka digunakan Persamaan 12-15.

$$
\begin{gathered}
P F_{1}=\left[\frac{\sum_{i-1}^{N}\left(w_{i} \phi_{i 1}\right) / g}{\left.\sum_{i-1}^{N}\left(w_{i} \phi_{i 1}{ }^{2}\right) / g\right]}\right. \\
\alpha_{1}=\frac{\left[\sum_{i-1}^{N}\left(w_{i} \phi_{i 1}\right) / g\right]^{2}}{\left[\sum_{i-1}^{N}\left(\frac{1 N_{i}}{\mathrm{~g}}\right)\right]\left[\sum_{i-1}^{N}\left(w_{i} \phi_{i 1}{ }^{2}\right) / \mathrm{g}\right]} \\
S_{\alpha}=\frac{V / W}{\alpha_{1}} \\
S_{d}=\frac{\Delta_{\text {roof }}}{P F_{1} \phi_{\text {roof }: 1}}
\end{gathered}
$$


Dimana $S_{a}=$ Spectral acceleration, $S_{d=\text { Spectral displacement, }} P F_{1=}$ modal participation untuk modal pertama, $\alpha_{1=}$ modal mass coefficient untuk modal pertama, $\Phi_{i 1}=$ amplitude of first untuk level $\mathrm{i}, \mathrm{V}=$ gaya geser dasar, $\mathrm{W}=$ berat mati bangunan ditambah beban atap, $\Delta_{\text {roof }}=$ roof displacement, dan wi/g $=$ massa pada level $\mathrm{i}$.

\section{Kinerja Struktur Metode FEMA 356}

Metode koefisien FEMA 356 adalah suatu pendekatan yang menyediakan perhitungan numerik langsung dari perpindahan global maksimum pada struktur. Penyelesaian dilakukan dengan memodifikasi respon elastis dari sistem SDOF ekuivalen dengan faktor koefisien $C_{0}, C_{1}, C_{2}, C_{3}$ sehingga diperoleh perpindahan global maksimum (elastis dan inelastis) yang disebut target perpindahan $\left(\delta_{T}\right)$.

$$
\delta_{T}=C_{0} C_{1} C_{2} C_{3} S_{a} \frac{T_{e}^{2}}{4 \pi^{2}} \mathrm{~g}
$$

Dimana $\delta_{T}=$ target perpindahan, $C_{0}=$ koefisien faktor bentuk, untuk merubah perpindahan spectral menjadi perpindahan atap, $C_{1}=$ faktor modifikasi untuk menghubungkan perpindahan inelastic maksimum dengan perpindahan respons elastik linier, $C_{2}=$ koefisien untuk memperhitungkan efek "pinching” dari hubungan beban deformasi akibat degradasi kekakuan dan kekuatan, $C_{3}=$ koefisien untuk memperhitungkan pembesaran lateral akibat adanya efek P-Delta, dan $\alpha=$ rasio kekakuan pasca leleh terhadap kekakuan elastis efektif.

\section{Kinerja Struktur Metode FEMA 440}

Metode FEMA 440 merupakan metode pengembangan dari metode koefisien perpindahan FEMA 356 atau juga bisa disebut metode koefisien perpindahan yang diperbaiki. Secara garis besar dasar dalam perhitungan metode FEMA 440 ini sama dengan FEMA 356, yaitu dengan hasil akhir menentukan nilai target perpindahan $\left({ }^{\delta_{T}}\right)$. Perbaikan atau modifikasinya diberikan untuk menentukan parameter $C_{1}$ dan $C_{2}$.

\section{Batasan Deformasi}

Deformasi lateral pada saat performance point harus dicek terhadap deformasi limit yang ditetapkan dalam ATC-40, 1996 bab 11.3.3. Deformasi limit pada berbagai tingkat kinerja dilihat pada Tabel 1.

Tabel 1. Batasan simpangan pada tingkat kinerja struktur (Sumber : ATC-40, $1996: 11-4)$

\begin{tabular}{lcccc}
\hline \multicolumn{5}{c}{ Tingkat Kinerja } \\
\hline $\begin{array}{l}\text { Interstory Drift Limit } \\
\text { (Batas Simpangan Antar Lantai) }\end{array}$ & $\begin{array}{l}\text { Immediate } \\
\text { Occupancy }\end{array}$ & $\begin{array}{c}\text { Damage } \\
\text { Control }\end{array}$ & $\begin{array}{c}\text { Life } \\
\text { Safery }\end{array}$ & $\begin{array}{c}\text { Structural } \\
\text { Stability }\end{array}$ \\
$\begin{array}{l}\text { (Simpangan Total Drift } \\
\text { Maximum Inelastic Drift }\end{array}$ & 0.01 & $0.01-0.02$ & 0.02 & $0.33 \mathrm{Vi} / \mathrm{Pi}$ \\
(Simpangan Nonelastik Maks.) & 0.005 & $0.005-0.015$ & No Limit & No Limit \\
\hline
\end{tabular}

Pada desain baru, level kinerja yang direkomendasikan adalah Live Safety Level, saat simpangan total maksimum 0.02, hal ini dikarenakan pada berbagai eksperimen yang dilakukan menghasilkan respon dengan deformasi yang besar sehingga proporsional untuk detailing pada bangunan baru. (ATC-40, 1996: 11-5).

\section{PROSEDUR ANALISIS}

Berikut prosedur yang dilakukan dalam penelitian ini:

1. Penggambaran struktur, yakni penentuan grid line pada portal, tinggi bangunan, dan letak as.

2. Penentuan material struktur, yakni mutu beton, mutu baja.

3. Penentuan dimensi elemen struktur, yakni elemen balok, kolom, dinding geser, dan pelat.

4. Penggambaran model elemen struktur, yakni elemen balok, kolom, dinding geser, dan pelat.

5. Perhitungan pembebanan pada struktur, terdapat beban mati, beban hidup, dan beban gempa dengan SNI 1726:2012.

6. Analisis struktur dengan program ETABS untuk menentukan gaya dalam pada model struktur.

7. Desain penulangan balok, kolom, dan dinding geser. 
8. Memasukan data tulangan kedalam properti penampang elemen struktur, yakni balok, kolom, dan dinding geser.

9. Menambahkan sendi plastis pada balok dan kolom.

10. Melakukan analisis kapasitas struktur dengan analisis pushover.

11. Merencanakan gaya gempa rencana dan kinerja struktur dengan metode $D D B D$.

12. Menyimpulkan kinerja struktur hasil analisis pushover dengan perencanaan metode $D D B D$.

\section{ANALISIS DAN PEMBAHASAN}

\section{Analisis Gempa SNI 1726:2013}

Perencanaan struktur gedung yang akan dievaluasi terlebih dahulu direncanakan dengan perencanaan gempa berdasarkan SNI 1726:2012, sehingga didapat gaya geser rencana sebesar 12255.78 KN sebagai perencanaan awal untuk dievaluasi dengan analisis pushover.

\section{Kurva Kapasitas}

Dari hasil analisis pushover dengan program bantu ETABS didapatkan kurva kapasitas untuk masing-masing arah gedung.

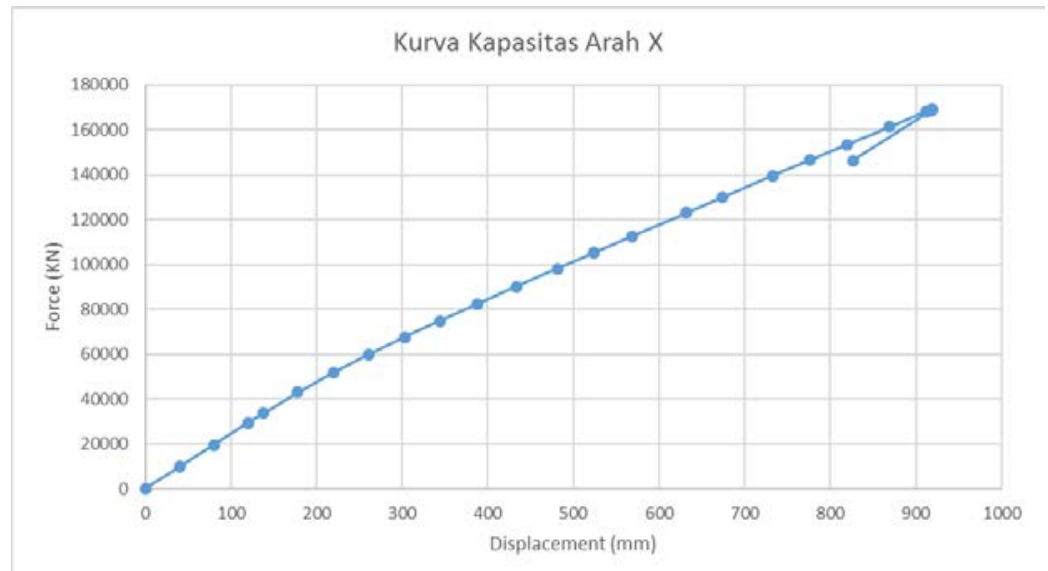

Gambar 2. Kurva kapasitas arah X

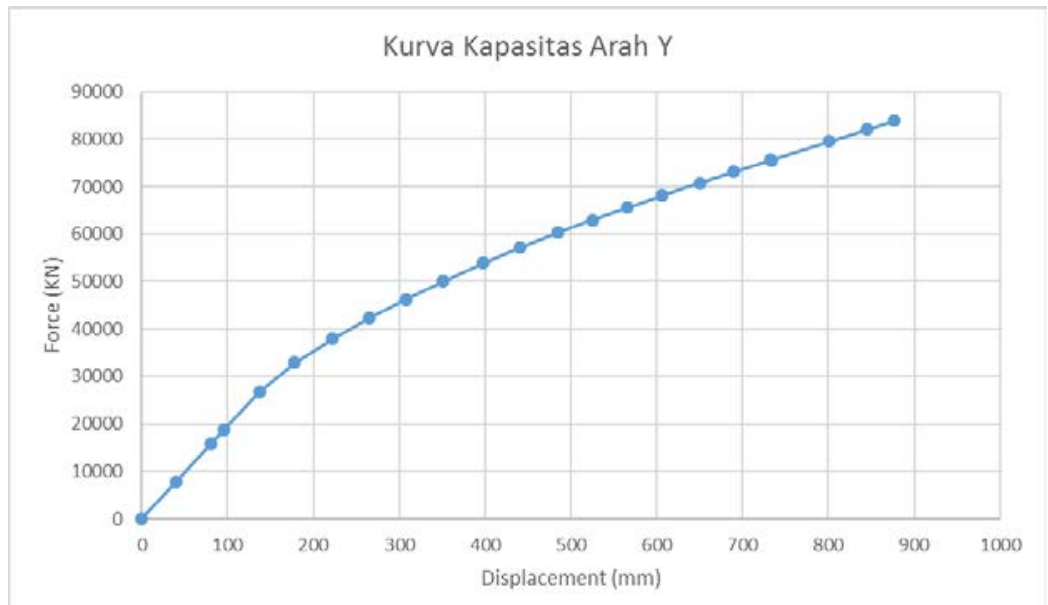

Gambar 3. Kurva kapasitas arah Y

\section{Metode Spektrum Kapasitas ATC-40}

Pada metode ATC-40 diambil kurva spektrum kapasitas yang didapat pada running analisis pushover dengan program ETABS. Untuk mendapatkan performance point maka dibutuhkan kurva respon spektrum yang sudah 
dikonversi kedalam format $A D R S$ dan mendapatkan performance point setelah mendapatkan titik perpotongan kurva spektrum kapasitas dengan kurva respon spektrum.

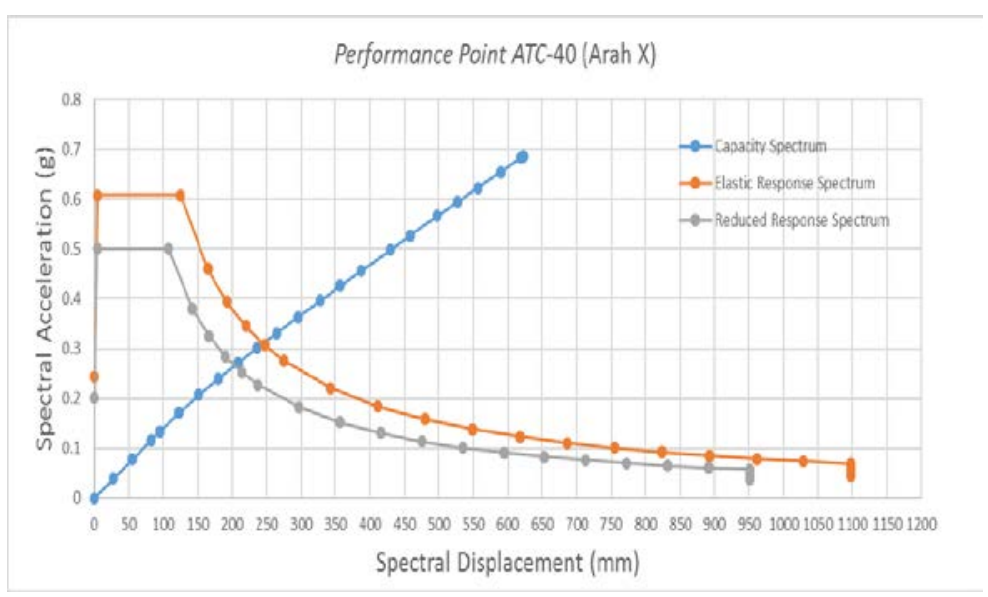

Gambar 4. Performance point arah X

Maka kinerja struktur untuk rangka arah X dengan mencari nilai drift rata-rata tiap lantai dengan total tinggi lantai = $64.5 \mathrm{~mm}$

Arah $\mathrm{X}=0.2652 / 64.5=0.00411$ (Immediate Occupancy)

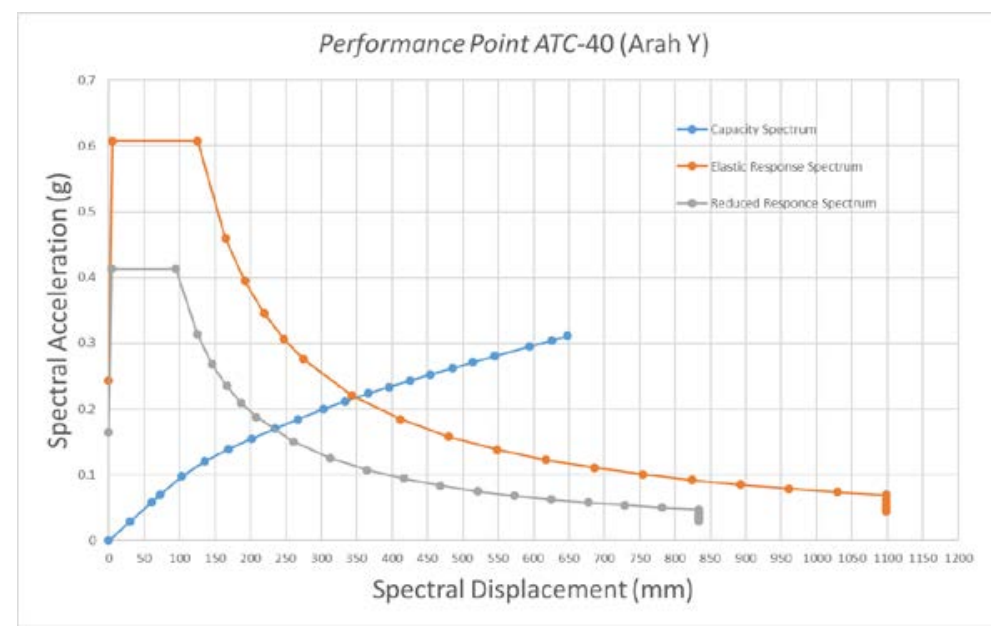

Gambar 5. Performance point arah Y

Maka kinerja struktur untuk rangka arah Y dengan mencari nilai drift rata-rata tiap lantai dengan total tinggi lantai = $64.5 \mathrm{~mm}$

Arah $\mathrm{Y}=0.311 / 64.5=0.00482$ (Immediate Occupancy)

\section{Metode Koefisien Perpindahan FEMA 356}

Pada metode FEMA 356 diambil kurva idealisasi bilinier (kurva biner pushover) yang didapat pada program ETABS. Dan perhitungan target perpindahan ditabelkan pada Tabel 2. 


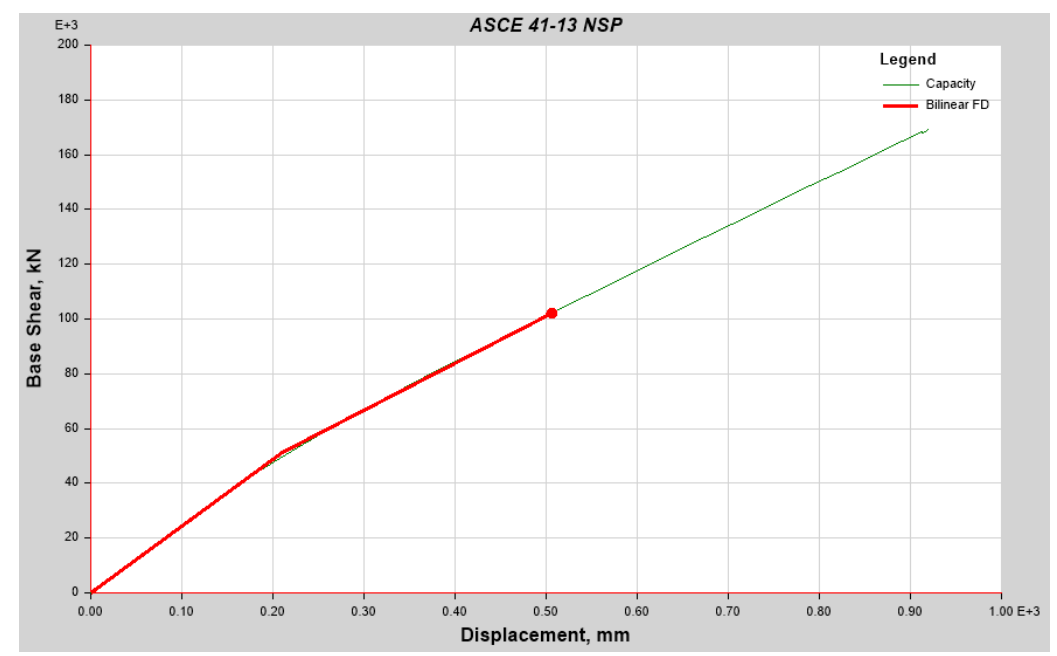

Gambar 6. Kurva biner pushover arah X (Sumber : ETABS)

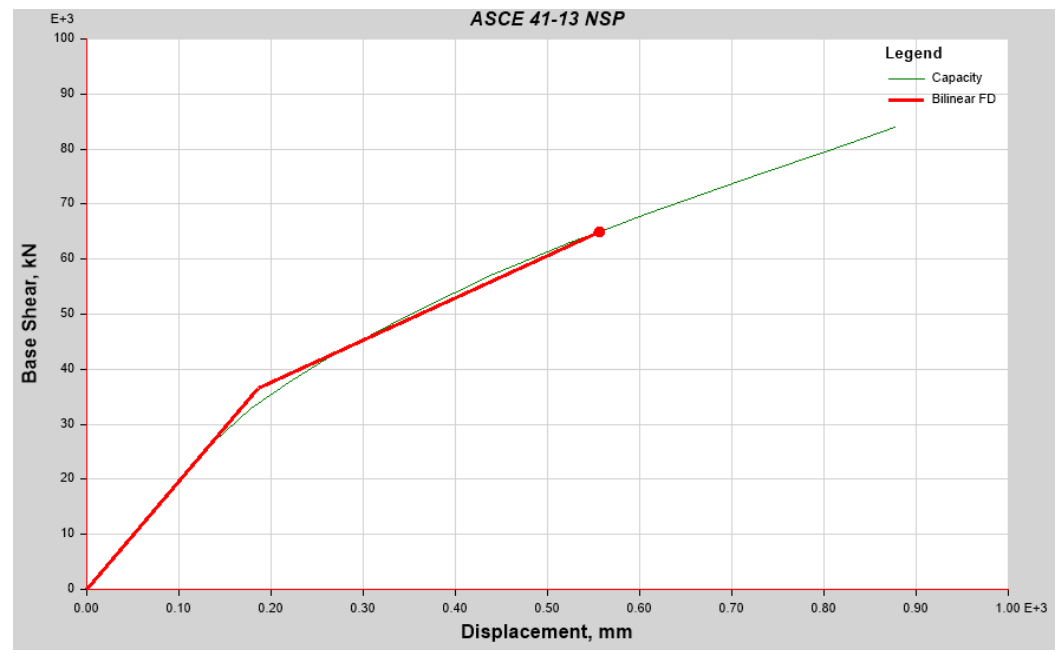

Gambar 7. Kurva biner pushover arah Y (Sumber : ETABS)

Tabel 2. Perhitungan Target Perpindahan FEMA 356

\begin{tabular}{ccc}
\hline Parameter Hitungan & Arah X & Arah Y \\
\hline Berat Total $(\mathrm{KN})$ & 362301.9278 & 362301.9278 \\
\hline Vbase Yield $(\mathrm{KN})$ & 51172.4249 & 36548.0769 \\
\hline Yield Displacement $(\mathrm{mm})$ & 209.96 & 185.91 \\
\hline Kekakuan Awal $(\mathrm{KN} / \mathrm{m})$ & 243724.6379 & $1,965,901,614$ \\
\hline Kekakuan Efektif $(\mathrm{KN} / \mathrm{m})$ & 243724.6379 & $1,965,901,614$ \\
\hline Periode Awal $(\mathrm{s})$ & 1.692 & 2.051 \\
\hline Periode Efektif $(\mathrm{s})$ & 1.692 & 2.051 \\
\hline C0 & 1.5 & 1.5 \\
\hline C1 & 1 & 1 \\
\hline Ts & 1.0994 & 1 \\
\hline C2 & 1 & 0.2693 \\
\hline Sa & 0.3265 & 2.6695 \\
\hline R & 2.312 & 0.39018 \\
\hline alfa & 0.7071 & 1.4103 \\
\hline C3 & 1.628 & 0.7219 \\
\hline Target Perpindahan $(\mathrm{m})$ & 0.5672 &
\end{tabular}




\section{Metode Koefisien Perpindahan FEMA 440}

Untuk metode FEMA 440 digunakan cara yang sama dengan FEMA 356 yaitu menggunakan kurva idealisasi dari analisa pushover. Hanya ada perbedaan dalam menentukan nilai faktor modifikasi $C_{1}$ dan faktor modifikasi $C_{2}$. nilai $C_{1}=1.0$ dan nilai $C_{2}=1.0$ untuk non-degrading system, sehingga faktor modifikasi $C_{1}$ dan faktor modifikasi $C_{2}$ bernilai sama dengan FEMA 356, sehingga target perpindahannya juga sama dengan FEMA 356.

\section{Metode Direct Displacement Based Design}

Langkah awal dalam analisis DDBD untuk dual system adalah menentukan rasio gaya geser. Rasio gaya geser mengikuti rasio yang dihasilkan melalui respon elastis, dengan rasio untuk arah $\mathrm{X}, \beta \mathrm{f}=28.5377 \%$ dan untuk arah $\mathrm{Y}$, $\beta \mathrm{f}=43.763 \%$. Selanjutnya dilakukan perhitungan dalam menentukan perpindahan rencana SDOF dan ditabelkan pada Tabel 3.

Tabel 3. Perhitungan Gaya Geser Metode DDBD

\begin{tabular}{ccc}
\hline Parameter Hitungan & Arah X & Arah Y \\
\hline Berat Total $(\mathrm{KN})$ & 362301.9278 & 362301.9278 \\
\hline Vbase Yield $(\mathrm{KN})$ & 51172.4249 & 36548.0769 \\
\hline Yield Displacement $(\mathrm{mm})$ & 209.96 & 185.91 \\
\hline Kekakuan Awal $(\mathrm{KN} / \mathrm{m})$ & 243724.6379 & $1,965,901,614$ \\
\hline Kekakuan Efektif $(\mathrm{KN} / \mathrm{m})$ & 243724.6379 & $1,965,901,614$ \\
\hline Periode Awal $(\mathrm{s})$ & 1.692 & 2.051 \\
\hline Periode Efektif $(\mathrm{s})$ & 1.692 & 2.051 \\
\hline C0 & 1.5 & 1.5 \\
\hline C1 & 1 & 1 \\
\hline Ts & 1.0994 & 1.0994 \\
\hline C2 & 1 & 0.2693 \\
\hline Sa & 0.3265 & 2.6695 \\
\hline R & 2.312 & 0.39018 \\
\hline alfa & 0.7071 & 1.4103 \\
\hline C3 & 1.628 & 0.7219
\end{tabular}

Dari hasil perhitungan seperti yang sudah ditabelkan pada Tabel 3, didapat nilai gaya geser base sebagai gaya geser rencana untuk metode perencanaan metode $D D B D$. Dimana gaya geser rencana mengacu pada perpindahan maksimum struktur gedung.

\section{KESIMPULAN}

Dari hasil analisis berbasis kinerja pada gedung dual system dengan beberapa metode yang telah dilakukan sebelumnya, dapat disimpulkan bahwa :

- Dari hasil analisis pushover yang dianalisis terjadi sendi plastis yang sesuai dengan teori weak beam strong column, yaitu semua struktur leleh terlebih dahulu kemudian kolom pada lantai dasar.

- Gaya geser dasar yang didapat dalam perhitungan analisis gempa metode $D D B D$ lebih besar dari gaya geser dasar analisis gempa menurut SNI 1726:2012. Perbedaan nilai gaya geser ini disebabkan oleh perencanaan metode $D D B D$ yang mengacu pada perpindahan maksimum model gedung sebagai acuan rencana, sehingga dapat disimpulkan bahwa perencanaan dengan $D D B D$ lebih kuat pada struktur dibandingkan dengan perencanaan SNI 1726:2012 tetapi menyebabkan biaya yang lebih mahal.

- Kinerja struktur dengan perencanaan SNI 1726:2012 untuk metode ATC-40 mendapat level kinerja yang lebih baik yaitu immediate occupancy dimana kondisi gedung hampir sama sebelum terjadinya gempa dan dapat digunakan kembali, sedangkan dengan metode FEMA 356 dan FEMA 440 mendapat level kinerja yang lebih buruk yaitu damage control dimana kondisi gedung belum mengalami kerusakan dan dapat difungsikan kembali sehingga dapat disimpulkan bahwa metode terbaru dari FEMA 356 dan FEMA 440 mendapatkan kinerja struktur yang lebih buruk tetapi lebih detail dalam hal keamanan. 
- Kinerja struktur dengan perencanaan SNI 1726:2012 yang didapat dengan analisis pushover belum mencapai level kinerja structural stability sehingga dapat disimpulkan perencanaan SNI 1726:2012 masih aman dan belum mencapai ambang batas keruntuhan struktur.

\section{DAFTAR PUSTAKA}

ASCE 7-10. (2010). Minimum Design Loads for Buildings and Other Structures. Virginia: American Society of Civil Engineers.

ATC-40. (1996). Seismic Evaluation and Retrofit of Concrete Buildings. California: Applied Technology Council.

Badan Standarisasi Nasional. (2012). Tata Cara Perencanaan Ketahanan Gempa untuk Struktur Bangunan Gedung dan non Gedung (SNI 1726:2012). Jakarta: BSN.

Badan Standarisasi Nasional. (2013). Beban Minimum Untuk Perancangan Bangunan Gedung dan Struktur Lain (SNI 1727:2013). Jakarta: BSN.

Computers and Structures, Inc. (2016). CSi Analysis Reference Manual. California: Computers and Structures, Inc.

FEMA 273. (1997). NEHRP Guidelines for the Seismic Rehabilitation of Buildings. Washington, D.C: Federal Emergency Management Agency.

FEMA 356. (2000). Prestandard and Commentary for the Seismic Rehabilitation of Buildings. Wasington, D.C: Federal Emergency Management Agency.

FEMA 440. (2005). Improvement of Nonlinier Static Seismic Analysis Procedures. Wasington, D.C: Federal Emergency Management Agency.

Priestley, M. J., \& Kowalsky, M. J. (2007). Displacement-Based Seismic Design of Structures. Pavia: IUSS Press.

Sullivan T. J., P. M., \& Calvi, G. M. (2006). “Direct displacement based design of frame-wall structures”. Journal of Earthquake Engineering, V. 10, 91.

Tavio, \& Wijaya, U. (2018). Desain Rekayasa Gempa Berbasis Kinerja. Jakarta: ANDI Yogyakarta.

Y.Fahjan, B. B. (2012). Pushover Analysis For Performance Based-Seismic Design OF RC Frames with Shear Walls. 15 MCEE.

Anwar, D. N. (2011). Performance Based Design. ASEP Seminar. Thailand: AIT Consulting.

Tall Buildings Initiative. (2017). Guidelines for Performance-Based Seismic Design of Tall Buildings. California: Pasific Earthquake Engineering Centre. 